\title{
Bioremediation of Heavy Metal Chrome with Saccharomyces cerevisiae in Industrial Metal Plating Liquid Waste
}

\author{
Mardiyono \\ Universitas Setia Budi \\ Surakarta, Indonesia \\ mardiyono.md@gmail.com
}

\author{
Nur Hidayati \\ Universitas Setia Budi \\ Surakarta, Indonesia \\ nurhidayati.nh@gmail.com
}

\author{
Nony Puspawati \\ Universitas Setia Budi \\ Surakarta, Indonesia \\ nonyksolo@yahoo.co.id
}

\begin{abstract}
- the metal plating industry realistically and continually produce liquid waste in a number of relatively small but highly toxic. This waste disposal will poison the surrounding environment as well as biotic/abiotic component, if the waste directly disposed of into the environment without being processed first. The purpose of this research is to process liquid waste from the metal-plating industry containing Chrome heavy metals using bioremidiation with spesific microbes. Research was conducted by bioremidiation using Saccharomyces cerevisiae microbes with concentration variation of $10^{2.5}$ and $10^{5}$ and curing time for 48 hours. The results showed that the initial levels of Chromium metal plating liquid waste before processing was $1.35 \mathrm{ppm}$. Metal plating liquid waste processing in Saccharomyces cerevisiae microbes with bioremidiation can lower the levels of Chrome to $0.297 \mathrm{ppm}$ with a percentage decrease level of $78.03 \%$. The bioremidiation process with concentration of $10^{5}$ Saccharomyces cerevisiae can decrease Chrome levels significantly.
\end{abstract}

Keywords-bioremidiation, chrome heavy metal, metal plating liquid waste, Saccharomyces cerevisiae

\section{INTRODUCTION}

Disposal of metal plating liquid waste industry will poison the surrounding biotic and abiotic environment if the waste is directly discharged into the environment without being processed first. There is an alternative method of industrial waste treatment that is considered more secure and also beneficial for the environment that is biological waste processing.

$\mathrm{Cr}$ (VI) contained in the wastewater of the tannery industry can be reduced by Pseudomonas aeruginosa to $\mathrm{Cr}$ (III) which is non-toxic [1]. Yarrowia lipolytica yeast is able to live well in medium containing Cadmium ion $(\mathrm{Cd})$ up to $200 \mathrm{ppm}$ [2]. In a 10-hour incubation period in a cadmiumcontaining waste, Yarrowia lipolytica yeast may absorb 50 percent of Cadmium. Pseudoctavianiomonas aeruginosa can reduce the level of Copper metal $(\mathrm{Cu})$ contained in the wastewater of metal coating industry of $81.3 \%$ [3]. The research on handling heavy metals in liquid wastes produced by industry by utilizing bacterial microbes and fungi as well as combination of Pseudomonas aeruginosa and Bacillus subtilis [4]. The results showed that bacterial microbe use can reduce the levels of Nickel $(\mathrm{Ni})$ and Chromium $(\mathrm{Cr})$ in industrial wastewater.
Therefore, this research was conducted to reduce the heavy metal level of Chromium $(\mathrm{Cr})$ contained in industrial metal plating liquid waste by bioremidiation using variation of microbial concentration of Saccharomyces cerevisiae with curing time for 48 hours.

\section{MATERIALS AND METHOD}

\section{A. Apparatus}

Apparatus used in this research such as: Atomic absorption spectrophotometer (AAS), quvet, $\mathrm{pH}$ meter, bottles, $50 \mathrm{~mL}$ flask, $1 \mathrm{~mL}$ volume pipette, suction, centrifuge, filter paper, test tube, and dropper pipette.

\section{B. Chemicals and reagents}

Chemicals and reagents used in this research such as: industrial metal plating liquid waste, Saccharomyces cerevisiae, $\mathrm{H}_{2} \mathrm{SO}_{4} 0.2 \mathrm{~N}$, concentrated $\mathrm{HNO}_{3}, \mathrm{Ca}(\mathrm{OH})_{2}$, $\mathrm{K}_{2} \mathrm{Cr}_{2} \mathrm{O}_{7}$, 1,5-Diphenyl carbazide, Aquades, Paper label, Filter paper, Acetone.

\section{Metal palting liquid waste treatment with} bioremediation

Bioremidiation is carried out to treat liquid wastewater metals with Saccharomyces cerevisiae with varying concentrations. Bioremediation consist of three phases, such as:

1) Saccharomyces cerevisiae suspension preparation: Saccharomyces cerevisiae are cultured on an appropriate medium. Taken 2-3 ose then included in $100 \mathrm{ml}$ of medium, then incubated at $37^{\circ} \mathrm{C}$ for 24 hours.

2) Administration of Saccharomyces cerevisiae on metal coating waste samples: Samples from the electrocoagulation process of 1 liter in a 1.5 liter water bottle were treated with the addition of Saccharomyces cerevisiae with concentrations of 102.5 cells $/ \mathrm{ml}$ and 105 cells $/ \mathrm{ml}$, then

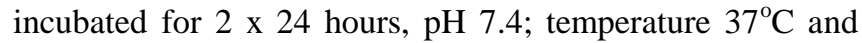
then set the weight of the metal [5].

3) Testing the liquid metal plating wastewater samples prior to processing with Saccharomyces cerevisiae: The test sample was taken $100 \mathrm{ml}, \mathrm{HNO}_{3}$ concentrate was added 5 $\mathrm{ml}$ and heated to until the solution was almost dry, then 50 $\mathrm{ml}$ of aquabidestilata was added and put into $100 \mathrm{ml}$ flask through Whatman filter paper and $100 \mathrm{ml}$ of $0.2 \mathrm{~N} \mathrm{H}_{2} \mathrm{SO}_{4}$ 
solution. The test solution was then transferred into cuvet and then read its absorbance using an Atomic Absorption Spectrophotometer (AAS) / UV-Vis Spectrophotometer (SNI 06-6989.17-2004).

\section{RESULTS}

The result of the research are presented in table and figure below.

A. Chromium level of heavy metal wastewater prior to processing by remidiation with Saccharomyces cerevisiae

TABLE I. CHROMIUM LEVEL OF HEAVY METAL WASTEWATER PRIOR TO PROCESSING BY BIOREMIDIATION WITH SACCHAROMYCES CEREVISIAE

\begin{tabular}{ccc}
\hline $\begin{array}{c}\text { Experiment } \\
\text { number }\end{array}$ & $\begin{array}{c}\text { Microbes concentrations } \\
\text { Saccharomyces } \\
\text { cerevisiae }\end{array}$ & $\begin{array}{c}\text { Chrome levels } \\
(\mathrm{ppm})\end{array}$ \\
\hline 1 & 0 & 1,35 \\
2 & 0 & 1,35 \\
3 & 0 & 1,35 \\
\hline
\end{tabular}

B. Chromium level of heavy metal wastewater after treatment by bioremidiation using variation of Saccharomyces cerevisiae concentration and curing time 48 hours

table II. Chromium LeVel Of Heavy Metal Wastewater AFter TREATMENT BY BIOREMIDIATION USING VARIATION OF SaCChaRomyces Cerevisiae Concentration AND CuRING Time 48 HOURS

\begin{tabular}{ccccc}
\hline No & $\begin{array}{c}\text { Microbes } \\
\text { concentrations } \\
\text { Saccharomyces } \\
\text { cerevisiae }\end{array}$ & $\begin{array}{c}\text { Chromium } \\
\text { levels } \\
(\mathrm{ppm})\end{array}$ & $\begin{array}{c}\text { Chromium } \\
\text { levels (ppm) } \\
\text { after } \\
\text { bioremediation }\end{array}$ & $\begin{array}{c}\text { Decreased } \\
\text { chromium } \\
\text { levels (ppm) }\end{array}$ \\
\hline 1 & 0 & 1,35 & 1,30 & 0,05 \\
& & 1,35 & 1,31 & 0,04 \\
2 & $10^{2,5}$ & 1,35 & 1,31 & 0,04 \\
& & 1,35 & 0,68 & 0.67 \\
3 & $10^{5}$ & 1,35 & 0,67 & 0,68 \\
& & 1,35 & 0,67 & 0,68 \\
& & 1,35 & 0,30 & 1,05 \\
& & 1,35 & 0,29 & 1,06 \\
& & & 0,30 & 1,05 \\
\hline
\end{tabular}

C. Percentage of chromium decrease after bioremidiation processing using variation of Saccharomyces cerevisiae concentration to initial concentration (1.35 ppm) and 48 hours of curing time

TABLE III. PERCENTAGE OF CHROMIUM DECREASE AFTER BIOREMIDIATION PROCESSING USING VARIATION SACCHAROMYCES CEREVISIAE CONCENTRATION (1.35 PPM) AND 48 HOURS OF CURING TIME

\begin{tabular}{cccc}
\hline No & $\begin{array}{c}\text { Consentration of } \\
\text { Saccharomyces } \\
\text { cerevisiae }\end{array}$ & $\begin{array}{c}\text { Percent } \\
\text { decrease }(\%)\end{array}$ & $\begin{array}{c}\text { Mean percentage } \\
\text { decrease }(\%)\end{array}$ \\
\hline 1 & 0 & $3,70$. & 3,21 \\
& & 2,96 & \\
2 & 10 & 2,96 & 50,12 \\
& & 49,63 & \\
3 & & 50,37 & 78,03 \\
& \multirow{2}{*}{$10^{2,5}$} & 50,37 & \\
& & 77,78 & \\
\hline
\end{tabular}

D. Chromium decrease percentage after bioremidiation processing using variation of Saccharomyces cerevisiae concentration on initial concentration (1.35 ppm) and 48 hours of curing time

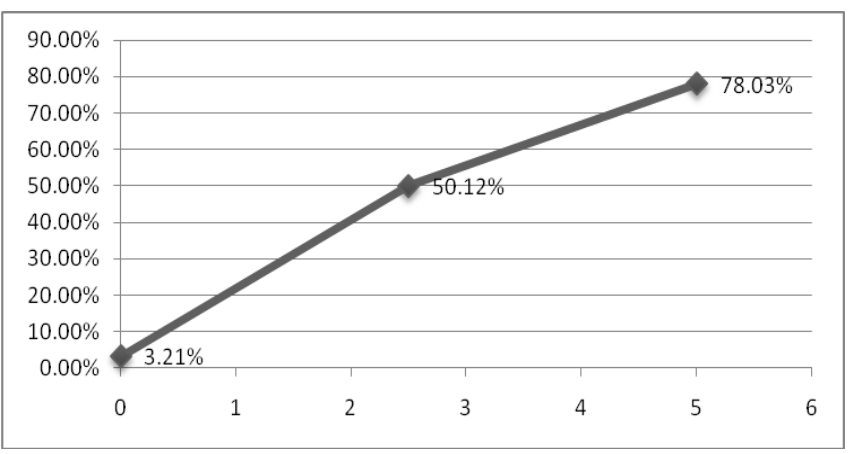

Fig. 1. Chromium decrease percentage after bioremidiation processing using variation of Saccharomyces cerevisiae concentration on initial concentration and curing time 48 hours

\section{DISCUSSION}

The result showed that preliminary levels of Chromium before the addition of Saccharomyces cerevisiae is shown in Table 1 (1.35 ppm). Table 2 illustrates the decrease in chromium level after processing with Saccharomyces cerevisiae concentration variations of $10^{2.5}$ and $10^{5}$, the results showed the addition of Saccharomyces cerevisiae with concentrations of $10^{5}$ lower levels of Chromium was higher than that of Saccharomyces cerevisiae with concentration of $10^{2.5}$.The decrease of chromium content from the beginning of $1.35 \mathrm{ppm}$ decreased to an average chromium level of $0.297 \mathrm{ppm}$. Table 3 shows a decrease in chromium content by $78.03 \%$.

The use of Saccharomyces cerevisiae to reduce chromium level is a form of bioremidiation that is the use of microbes for the handling of hazardous waste or soil to convert chemical compounds into harmless chemical compounds [7]. Most of the mechanism of heavy metal cleaning by microorganisms is the ion exchange process, so with this concept chromium level in hazardous waste can be lowered.

\section{CONCLUSIONS}

\section{A. Conclusions}

1) Initial chromium level of metal plating wastewater before processing is $1.35 \mathrm{ppm}$

2) Bioremidiation of metal plating wastewater treatment with Saccharomyces cerevisiae microbe can decrease Chromium heavy metal level to $0.297 \mathrm{ppm}$ with decreasing percentage of $78.03 \%$. The bioremidiation process with Saccharomyces cerevisiae with concentration of $10^{5}$ can significantly decrease chromium level.

\section{B. Recommendations}

1) Please follow up with the combined process of electrocoagulation and bioremidiation to treat the actual waste containing heavy metals. 
2) Require the design and manufacture of Wastewater Treatment Plant (WTP) with a simple model that can reduce / remove heavy metals in the liquid lime produced by industries containing heavy metals.

\section{ACKNOWLEDGMENT}

Mardiyono, Nur Hidayati, Nony Puspawati thanks to Direktorat Jenderal Penguatan dan Pengembangan Kementerian Riset, Teknologi, dan Pendidikan Tinggi who has funded the implementation of Applied Product Research (contract No. 002/LPPM-USB/PPT/IV/2017). Thanks to the Rector of Setia Budi University of Surakarta for the research opportunity.

\section{REFERENCES}

[1] Besmanto, N., Soetarto, E. S., \& Widodo, S. Detoksifikasi Krom Limbah Cair Penyamakan Kulit oleh Pseudomonas sp. Jurnal Teknosains, 16(2), 313-328. 2003.
[2] Octaviani, A. M. Biosorpsi Logam Kadmium Menggunakan Ragi Yarrowia lipolityca strain H.222. Skripsi. Jurusan Kimia Universitas Negeri Yogyakarta. 2005.

[3] Pamungkas, M. Penurunan Kadar Tembaga $(\mathrm{Cu})$ dalam Limbah Cair Industri Pelapisan Logam dengan Menggunakan Bakteri Pseudomonas aeruginosa. Skripsi. Fakultas Farmasi Universitas Setia Budi Surakarta. 2006.

[4] Mardiyono, Nony Puspawati, Nur Hidayati. 2009. Aplikasi Mikroba Saccharomyces cerevisiae dalam Mereduksi Kadar Logam Berat Krom(VI) pada Limbah Cair Industri Tekstil. Jurnal Biomedika. Volume 1, No. 2, September 2009.

[5] Arinto, K. Upaya Penurunan Pencemaran Logam Berat Pb-II Dan CrVI Pada Air Lindi (Leachate) Melalui Proses Bioremediasi Dengan Penambahan Pseudomonas aeruginosa dan Bacillus subtilis. Tesis. Pascasarjana UNS. 2014.

[6] Arinto, K. Upaya Penurunan Pencemaran Logam Berat Pb-II Dan CrVI Pada Air Lindi (Leachate) Melalui Proses Bioremediasi Dengan Penambahan Pseudomonas aeruginosa dan Bacillus subtilis. Tesis. Pascasarjana UNS. 2014.

[7] Walker, S. Menyingkap Tabir Bioteknologi. Panduan Belajar Mandiri. Terjemahan oleh Amalia H. Hdinata, Ella Elvian. Jakarta. EGC. 2003. 